\title{
PEMBARUAN HUKUM ANTAR TATAHUKUM INDONESIA DALAM RANGKA MENDUKUNG PERKEMBANGAN EKONOMI DI ERA GLOBALISASI
}

(The Renewal of Indonesia Interlegal Law to Support Economy Development in Globalization)

\author{
Basuki Rekso Wibowo \\ Pusat Penelitian dan Pengembangan Hukum dan Peradilan Mahkamah Agung RI \\ JI. Jend. Ahmad Yani Kav.58, Jakarta Pusat, Indonesia \\ Email: basukireksowibowo@ymail.com
}

Naskah diterima: 15 Juni 2018; revisi: 4 Agustus 2018; disetujui: 6 Agustus 2018

\begin{abstract}
Abstrak
Keterlibatan Indonesia dalam hubungan perdagangan dengan negara negara lain telah berlangsung cukup lama. Hal yang tidak lepas dan terkait dengan hubungan perdagangan adalah dokumen kontrak, terlebih lagi kontrak dagang internasional yang mana terdapat perbedaan latar belakang status dan kedudukan hukum dari masing masing pihak yang terlibat. Tulisan ini menyoroti akibat hukum yang timbul dengan adanya klausula pilihan hukum dan pilihan forum dalam kontrak dagang internasional dan arah pembaruan hukum perdata internasional ke depan. Dengan menggunakan metode penelitian yuridis normatif melalui pendekatan perundang-undangan dan pendekatan konseptual didapati hasil bahwa dalam setiap perumusan kontrak dagang internasional diperlukan kehati-hatian dan kecermatan dari para pihak terhadap segala rumusan klausula dan substansi yang akan dimuat di dalamnya. Hal yang sangat penting untuk diperhatikan yaitu yang menyangkut pilihan hukum dan pilihan forum. Ketepatan melakukan pilihan hukum akan menentukan keabsahan kontrak dan penerapan hukum yang berlaku terhadap kontrak. Dan terhadap penyelesaian sengketa kontrak dagang internasional lebih tepat apabila dilakukan melalui forum arbitrase internasional yang disepakati, dimana arbitrase internasional tersebut dinilai memiliki reputasi tinggi serta putusannya dapat dimintakan pengakuan dan pelaksanaan di negara dari pihak yang menandatangani kontrak dagang internasional tesebut. Dan terhadap politik hukum yang menyangkut pembaruan hukum merupakan kebutuhan mendesak dalam rangka meningkatkan perekonomian sehingga perlu segera menyempurnakan RUU Hukum Perdata Internasional yang sudah ada untuk dimasukkan ke dalam prioritas Prolegnas.
\end{abstract}

Kata Kunci: kontrak, pilihan hukum, pilihan forum, hukum perdata internasional

\begin{abstract}
Indonesia's role in establishing trade relations with other countries has been conducted for a long time. Contract is one of the most important things in trade relation, moreover international contract where every related party has different background status and legal position. This writing focus to discuss about legal effect on choice of law and choice of forum clause in international trade contract and the prospect of private international law development in the future. Using juridical normative method, legislation and conceptual approach, it is found that every parties need to be careful in forming clause and substance of an international trade contract. The most important aspect to be considered is choice of law and choice of forum because it will determine the legitimacy of the contract and what law should be applied. If there's international trade contract dispute, it's better to settle it through an international arbitration forum as has been stipulated in the contract. This forum is considered to have good reputation and their decision can be acknowledged and executed in countries where the parties that have signed the contract come from. In terms of legal policy to support national economy development, there's an urgent need to finalize Private International Law Bill which is already in prioritized in National Legislation Program.
\end{abstract}

Keywords: contract, choice of law, choice of forum, private international law 


\section{A. Pendahuluan}

Dokumen kontrak memiliki kedudukan dan fungsi yang sangat penting untuk menandai terjadinya transaksi perdagangan. Menurut Black's Law Dictionary, contract is an agreement two or more parties creating obligations that are enforceable or otherwise recognizable at law. ${ }^{1}$ Pengertian ini berlaku baik pada kontrak dagang internasional maupun nasional. Menurut Huala Adolf, kontrak nasional merupakan kontrak yang dibuat oleh dua individu (subyek hukum) dalam suatu negara yang tidak ada unsur asingnya, sedangkan kontrak internasional merupakan kontrak yang di dalamnya terdapat unsur asing (foreign element). ${ }^{2}$ Berdasarkan rumusan pengertian Black's Law Dictionary tersebut bahwa para pihak dalam kontrak dapat terdiri dari dua pihak maupun lebih dari dua pihak sesuai dengan karakteristik masing masing kontrak kasus per kasus. Disebut sebagai kontrak internasional karena di dalamnya terkandung adanya unsur asing, baik yang menyangkut subyeknya, obyeknya, ataupun yang lainnya. Para pihak dalam yang terlibat dalam kontrak perdagangan internasional meliputi: hubungan antara perusahaan dengan perusahaan, antara negara dengan perusahaan, antara negara dengan negara, serta antara organisasi internasional dengan perusahaan, termasuk pula di dalamnya antara subyek hukum sebagai individu meskipun dalam skala yang sangat terbatas. $^{3}$

Berkenaan dengan terjadi perkembangan yang pesat di bidang teknologi komunikasi dan informasi dalam beberapa dekade belakangan ini telah membawa pengaruh besar terhadap cara dan bentuk transaksi perdagangan.
Transaksi perdagangan dapat berlangsung secara virtual dan impersonal. Para pihak tidak lagi mengadakan perjumpaan secara fisik satu sama lain dalam menandatangani dokumen kontrak pada waktu dan di tempat yang sama, sebagaimana pada model konvensional. Melainkan dilakukan melalui korespondensi secara elektronik, melalui email, faksimili, atau sarana elektronik yang lain saling melakukan komunikasi dan mengadakan kesepakatan kesepakatan, meskipun masing masing pihak berada di tempat yang berlainan. Hal yang demikian mengandung makna legal bahwa para pihak telah mengadakan kontrak secara elektronik dan mengikat para pihak. Kesepakatan dengan cara demikian dimaksudkan untuk mempertimbangkan aspek efisiensi dan efektifitas.

Menegaskan kembali uraian sebelumnya tentang kedudukan dan fungsi kontrak yang demikian penting dan menentukan kelangsungan hubungan hukum kontraktual itu sendiri, maka ketika merumuskan suatu kontrak perdagangan, terutama dalam transaksi perdagangan internasional masalah masalah yang menyangkut pilihan-pilihan menjadi agenda negosiasi para pihak. Meliputi pilihan hukum (choice of law) yang diberlakukan terhadap kontrak dan penyelesaian sengketa, pilihan forum (choice of forum) penyelesaian sengketa, pilihan tempat (choice of place) diselenggarakan penyelesaian sengketa, pilihan bahasa (choice of language) yang dipergunakan sebagai bahasa kontrak serta bahasa proses penyelesaian sengketa, pilihan mata uang (choice of currency) sebagai alat pembayaran, merupakan beberapa agenda negosiasi yang

Bryan Garner, Blacks Law Dictionary, seventh edition, (St.Paul, Minn: West Group, 1999), hlm. 318.

Huala Adolf, Dasar Dasar Hukum Kontrak Internasional, (Bandung: Refika Tama, 2007), hlm. 1.

Ibid, hlm. 47-67. 
sangat penting. Kendatipun demikian dengan pernyataan tersebut tidak lantas dapat dimaknai seolah-olah, quon non, bahwa hal hal yang lain bukan merupakan agenda yang tidak terlalu penting untuk dinegosiasikan. Berbagai hal yang lain tetap penting dan harus diperhatikan secara seksama dan komprehensip dalam setiap negosiasi penyusunan kontrak perdagangan.

Dalam konteks tulisan ini, saya hanya membatasi diri hendak menyoroti aspek hukum terkait pilihan-pilihan yang timbul dalam perumusan kontrak dagang internasional dan menganalisis akibat hukum yang timbul dengan adanya klausula pilihan hukum dan pilihan forum dalam kontrak dagang internasional, hal tersebut mengingat adanya perbedaan latar belakang status dan kedudukan hukum dari masing masing pihak yang terlibat dalam kontrak dagang internasional. Dan di dalam tulisan ini juga akan menggambarkan arah pembaruan Hukum Antar Tata Hukum yang terkait dengan hukum perdata internasional dalam rangka meningkatkan ekonomi dalam perdagangan internasional.

\section{B. Metode Penelitian}

Metode yang digunakan dalam penulisan ini bersifat juridis normative. Pendekatan yang digunakan adalah pendekatan perundangundangan (statute approach) terkait dengan peraturan yang mengatur tentang masalah hukum antar tata hukum yang saat ini berlaku (ius constitutum) maupun hukum yang akan diberlakukan di kemudian hari (ius constituendum) serta pilihan forum dan pilihan hukum dalam kontrak. Selain itu juga digunakan pendekatan konseptual (conceptual approach) terkait dengan beberapa konsep hukum menyangkut tentang kontrak, kontrak dagang internasional, hukum antar tata hukum, hukum perdata internasional, pilihan hukum, pilihan forum dan sebagainya. Tahapan langkah dimulai dengan melakukan studi kepustakaan (library research) dengan menganalisis bahan hukum primer maupun bahan hukum sekunder. Selanjutnya dilakukan analisis dan pembahasan secara mendalam secara kualitatif, kemudian memberikan kesimpulan dan saran.

\section{Pembahasan}

\section{Beberapa Pilihan dan Prinsip Prinsipnya}

\section{a. Pilihan Hukum}

Pilihan hukum (choice of law) merupakan persoalan yang cukup penting dalam kontrak perdagangan internasional. Masalah pilihan hukum yang berlaku terhadap kontrak internasional (choice of law atau the law applicable to the contract) merupakan masalah klasik dalam hukum kontrak internasional yang begitu intens dibahas dan diperdebatkan dalam berbagai literatur. Hal tersebut antara lain disebabkan oleh karena menyangkut perbedaan status dan kedudukan para pihak yang masing masing tunduk pada sistem atau aturan hukum yang berlainan, sehingga oleh karenanya harus dipastikan terlebih dahulu hukum apa yang akan diberlakukan terhadap kontrak maupun terhadap akibat hukum yang ditimbulkannya. ${ }^{4}$

Choice of law dimaknai sebagai "the question of which jurisdiction's law should apply in a given case". Adapun choice of law clause, dimaknai sebagai " a contractual provision by which the parties designate the jurisdiction whose law will govern any disputes that may arise between the parties". Periksa Bryan A Garner, Blacks Law Dictionary, seventh edition (St.Paul Minn: West Group, 1999) h.234. Bandingkan dengan Hans Smith et., all., International Contract (New York: Matthe Bender, 1981) hlm. 1. Mauro Rubino Sammartano, International Arbitration Law (Deventer: Boston, Kluwer Law, 1990), hlm. 251. Sebagaimana dikutip oleh Huala Adolf, op.cit., 137-138. 
Terdapat beberapa prinsip terkait dengan masalah pilihan hukum yang meliputi: (a). prinsip kebebasan para pihak (partij autonomie), dimana para pihak memiliki kebebasan untuk mengadakan kesepakatan dalam memilih dan menerapkan hukum yang akan berlaku terhadap kontrak; (b). prinsip bonafide, dimana para pihak mengadakan pilihan hukum didasarkan adanya itikad baik sehingga oleh karena itu wajib menghormati dan melaksanakannya; (c). prinsip real connection, artinya hukum yang dipilih memang memiliki hubungan yang yang nyata dan masuk akal dengan para pihak maupun dengan kontrak yang bersangkutan; (d). prinsip separabilitas klausula pilihan hukum.

Sudargo Gautama mengatakan bahwa masalah pilihan hukum merupakan salah satu ajaran tersendiri di bidang hukum perdata internasional. Persoalan pilihan hukum dalam hukum perdata internasional memperlihatkan adanya unsur-unsur filsafat hukum, teori hukum, praktek hukum maupun politik hukum. ${ }^{5}$

Dalam praktek pembuatan kontrak dagang internasional, para pihak memiliki otonomi dalam melakukan pilihan hukum (choice of law). Terutama dalam kaitannya untuk menentukan hukum apa yang berlaku (governing law) atau hukum apa yang akan diterapkan (applicable law) terhadap kontrak beserta segala akibat hukumnya. Hukum pilihan para pihak (law of the parties) yang berkaitan dengan penyelesaian sengketa melalui arbitrase merupakan aturan hukum yang nantinya dipergunakan oleh arbiter sebagai landasan untuk menyelesaikan sengketa yang bersangkutan. Arbiter tidak boleh menggunakan aturan hukum lain, di luar hukum pilihan para para pihak. Namun demikian, kebebasan para pihak dalam melakukan pilihan hukum tidak dalam pengertian sebagai kebebasan tanpa pembatasan sama sekali. Penggunaan asas kebebasan berkontrak, termasuk dalam melakukan pilihan hukum, tetap memiliki batas batas tertentu.

Berkaitan dengan masalah tersebut kiranya penting untuk diperhatikan dalam melakukan pilihan hukum bahwa masalah "mandatory rules of public nature" dalam kaitannya dengan asas "public policy" yang memegang peranan sangat penting. Isu paling utama dalam masalah pilihan hukum adalah keseimbangan antara asas partij autonomie vs. asas public policy. Di satu pihak asas partij autonomie membenarkan adanya kebebasan untuk mengadakan pilihan hukum sesuai kehendak para pihak, namun di pihak lain, asas public policy membatasi luasnya pilihan hukum itu sendiri. Untuk memperjelas masalah tersebut, Setiawan dengan mengutip pendapat Rene van Rooy Maurice Polak, menyebutkan bahwa: "choice of law in civil and commercial matters is characterized by two contradictory phenomena: party autonomie and mandatory rules of public nature ${ }^{\prime \prime}{ }^{6}$

Menurut Huala Adolf, terdapat beberapa pembatasan terhadap choice of law antara lain meliputi: (a) tidak melanggar ketertiban umum; (b) sepanjang hanya menyangkut hukum kontrak; (c) memiliki kaitan dengan kontrak yang bersangkutan; (d). tidak dengan tujuan melakukan penyelundupan hukum; (e) tidak menyangkut transaksi tanah atau hak hak atas benda tak bergerak; ( $f$ ) tidak mengenai hukum perdata dengan sifat publik; (g) melanggar itikad baik; (h) untuk menghindari tanggungjawab 
pidana; (i). tidak melanggar hukum yang bersifat memaksa. $^{7}$

Memperhatikan alasan alasan pembatasan terhadap otonomi para pihak dalam melakukan pilihan hukum terkait dengan pembuatan kontrak, hal tersebut telah mencerminkan bahwa semakin hari penggunaan asas kebebasan berkontrak semakin proses penyempitan. Bahkan dalam perkembangan ilmu hukum dan praktek hukum di kemudian hari, tidak tertutup kemungkinan munculnya alasan alasan lain menyangkut tentang pembatasan penggunaan kebebasan berkontrak para pihak menyangkut pilihan hukum. Terutama yang berkaitan dengan perkembangan hukum administrasi yang mulai mendesak keberadaan kebebasan para pihak dalam mengadakan hubungan kontraktual, terutama yang menyangkut kontrak yang berdimensi administrasi.

Negara melalui sejumlah kebijakan, termasuk pengadilan melalui putusannya, memiliki peran untuk membatasi penggunaan kebebasan berkontrak untuk melindungi pihak yang lemah dalam hubungan kontratual serta menjaga terpeliharanya ketertiban umum. Juga dimaksudkan untuk melindungi kepentingan negara dan masyarakat luas. Penggunaan kebebasan berkontrak dengan pembatasan terhadap kebebasan telah terjadi tarik menarik satu sama lain. Dalam kaitannya dengan kontrak internasional, pada dasarnya setiap negara akan berusaha untuk menetapkan rambu rambu dalam sistem hukum nasionalnya sendiri menyangkut tentang pembatasan penggunaan kebebasan berkontrak, baik terhadap kontrak domestik, maupun terhadap kontrak internasional yang memiliki keterkaitan dengan kepentingan negara dan masyarakat negara yang bersangkutan.

Hal tersebut sebagai wujud dari tanggungjawab negara untuk melindungi kepentingan nasional dan rakyatnya sendiri. Meskipun pada dasarnya setiap negara di satu pihak menginginkan agar warganegaranya dapat turut serta terlibat dalam interaksi perdagangan internasional, dalam rangka untuk memajukan perekonomiannya, namun di pihak lain tetap perlu diantisipasi terhadap kemungkinan yang dapat merugikan kepentingan nasional masing masing negara. Namun demikian, hal tersebut haruslah dilakukan secara proporsional, sebab apabila negara bersikap yang over proteksionis justru akan menjadi hambatan serius dalam sistem dan interaksi perdagangan internasional. Negara yang bersikap over proteksionis cenderung akan dikucilkan oleh negara negara lain yang merasa dirugikan.

Dalam globalisasi perdagangan masing masing negara, terutama negara maju, mengharapkan agar berbagai kendala kendala prosedural dari masing masing negara yang lain dilonggarkan sedemikian rupa agar interaksi kontrak perdagangan internasional, termasuk pelaksanaannya, dapat berlangsung dengan lancar.

Undang-Undang Nomor 30 Tahun 1999 tentang Arbitrase dan Alternatif Penyelesaian Sengketa (untuk selanjutnya disebut UUAAPS) Pasal 56 ayat (1) mengatur bahwa arbitrator atau majelis arbitrase mengambil putusan berdasarkan ketentuan hukum atau berdasarkan keadilan dan kepatutan. Kata "atau" pada ketentuan tersebut menunjukkan sifat alternatif kaidah hukum tersebut. Putusan "berdasarkan hukum" adalah putusan yang berdasarkan

Huala Adolf, Dasar Dasar Hukum Kontrak Internasional, op., cit., hlm. 154-157. 
hukum pilihan para pihak. Choice of law by the parties akan menjelma menjadi applicable law by court of arbitration. Terkecuali apabila para pihak sedari semula tidak mengadakan pilihan hukum tertentu, maka dalam situasi demikian itu, arbitratorlah yang akan menentukan hukum yang tepat untuk dijadikan sebagai landasan dalam putusan arbitrase.

Putusan arbitrase dapat juga berdasarkan ex aequo et bono apabila hal tersebut memang secara tegas-tegas telah diperjanjikan secara tertulis oleh para pihak. Tanpa adanya kesepakatan para pihak yang dituangkan dalam perjanjian arbitrase maka, arbitrator atau majelis arbitrase tidak berwenang memutus sengketa berdasar prinsip ex aequo et bono. Dengan adanya kewenangan memutus berdasarkan ex aequo et bono maka arbitrator dapat mengenyampingkan peraturan perundang undangan yang berlaku, kecuali terhadap hukum yang bersifat memaksa. Bagaimanapun juga ketentuan hukum yang bersifat memaksa (dwingend recht, compulsory law) merupakan aturan hukum yang bersifat mengikat dan tidak dapat disimpangi dengan dalih dan alasan apapun juga.

Pilihan hukum terhadap ketentuan hukum materiil merupakan hal yang umum dijumpai dalam kontrak perdagangan internasional. Mengingat adanya perbedaan status dan kedudukan hukum para pihak. Dengan perkataan lain terdapat adanya unsur asing dalam kontrak tersebut. Adapun dalam kontrak perdagangan yang bersifat nasional, oleh karena di dalamnya tidak mengandung sifat asing, maka masalah pilihan hukum menjadi sesuatu yang tidak relevan. Pihak-pihak yang memiliki status dan kedudukan hukum yang sama serta dikuasai oleh ketentuan hukum yang sama, maka dengan sendirinya mereka tunduk pada aturan hukum nasional yang sama pula. Justru akan menjadi sangat janggal dan menimbulkan pertanyaan besar apabila dalam kontrak dilakukan pilihan terhadap hukum asing, padahal para pihak dikuasai oleh hukum nasional yang sama. Terkecuali apabila kontrak perdagangan tersebut menyangkut objek kontrak, berupa barang bergerak maupun barang tidak bergerak, yang berada di wilayah negara lain yang memiliki sistem hukum berbeda, sehingga kepadanya berlaku hukum di negara yang bersangkutan. Dalam kasus yang terakhir maka masalah pilihan hukum tetap relevan, karena terdapat adanya unsur asing yang menyangkut objek kontrak.

Perbedaan lain yang bersifat karakteristik, antara penyelesaian sengketa secara litigasi melalui lembaga peradilan dengan melalui arbitrase, adalah menyangkut pilihan hukum formil, atau hukum acara prosedural. Pada penyelesaian sengketa secara litigasi di muka pengadilan berlaku ketentuan bahwa hukum formil atau hukum acara prosedural merupakan hukum yang bersifat memaksa (dwingend recht) sehingga harus dipatuhi dan tidak dapat disimpangi oleh hakim maupun para pihak berperkara. Adapun pada proses arbitrase, terdapat kemungkinan bagi para pihak untuk memilih hukum acara prosedural arbitrase berdasarkan kesepakatan mereka sendiri.

Pilihan hukum terhadap hukum formil (acara) diatur pasal 31 ayat (1) dan pasal 34 ayat (2) UUAAPS.

Pasal 31 ayat (1) mengatur bahwa:

"para pihak dalam suatu perjanjian tertulis yang dirumuskan secara tegas memiliki kebebasan untuk menentukan acara arbitrase yang digunakan dalam pemeriksaan sengketa sepanjang tidak bertentangan dengan undang-undang".

Pasal 34 ayat (2) mengatur bahwa: 
"Penyelesaian sengketa melalui arbitrase sebagaimana dimaksud dalam ayat (1) dilakukan menurut peraturan dan acara dari lembaga yang dipilih, kecuali ditetapkan lain oleh para pihak".

Dalam penjelasannya disebutkan bahwa: "ayat ini memberikan kebebasan kepada para pihak untuk memilih peraturan atau acara yang akan digunakan dalam penyelesaian sengketa diantara mereka tanpa harus menggunakan peraturan dan acara dari lembaga arbitrase yang dipilih".

Dengan adanya frasa "perkecualian" tersebut maka secara a contrario mengandung makna bahwa para pihak dalam kontrak boleh memilih ketentuan hukum acara yang lain yang mereka sepakati bersama. Hal yang sama juga diatur dalam Pasal 4 ayat (2) Peraturan Prosedur Badan Arbitrase Nasional Indonesia (BANI) bahwa:

" adalah dimungkinkan bahwa BANI atas persetujuan kedua belah pihak memeriksa dan memutuskan suatu sengketa dengan memakai ketentuan-ketentuan prosedur diluar dari bentuk ketentuan-ketentuan prosedur BANI. Persetujuan yang demikian harus dinyatakan secara tegas dalam bentuk tertulis.

Secara konseptual, apabila ditinjau dari sifatnya, bahwa hukum formil (acara) pada dasarnya merupakan hukum yang bersifat memaksa (dwingend recht) sehingga oleh karenanya berlaku mengikat terhadap semua pihak, baik hakim, arbiter, maupun para pihak berperkara, yang dengan alasan apapun para pihak tidak diperkenankan untuk menyimpanginya. Hukum formil mengatur tentang syarat dan prosedur acara, sehingga segala sesuatu yang menyangkut proses serta tahapannya harus dipenuhi oleh para pihak.
Namun demikian dalam proses arbitrase, terdapat kekhususan dan keunikan tersendiri, dimana para pihak memiliki kebolehan melakukan pilihan hukum acara. Terkait perihal tersebut Mauro Rubino Sammartano mengatakan bahwa:

"It has been widely debated in the past wheter the procedural law could be different from the substantive law and a positive conclusion has now been reached. A conclusion which nowdays may seem obvious, but which was a real struggle to reach. ${ }^{8}$

Terlepas dari berbagai kemungkinan dalam praktek, ketentuan dalam UUAAPS mencerminkan prinsip otonomi para pihak dalam menentukan acara arbitrase. Pasal 31 ayat (2) UUAAPS mengatur bahwa apabila para pihak tidak menentukan sendiri ketentuan mengenai acara arbitrase yang akan digunakan dalam pemeriksaan maka yang akan menentukan adalah arbitrator atau majelis arbitrase.

Persoalan pilihan hukum tidak sematamata ditentukan berdasarkan kebebasan para pihak, melainkan terdapat prinsip-prinsip penting yang juga perlu untuk diperhatikan. Menurut Sudargo Gautama, bahwa pilihan hukum suatu negara harus diartikan sebagai langsung menunjuk kepada hukum intern (sachnormen) daripada negara tersebut dan bukan kaidah hukum perdata internasionalnya ("any designation of a state shall be construed unless otherwise expressed, as directly referring to the substantive law of that state and not its conflict of laws rules").

Apabila para pihak ternyata para pihak tidak mengadakan pilihan hukum, maka panel arbitrase yang akan menggunakan hukum yang dianggap paling tepat dalam penyelesaian

8 Mauro Rubino Sammartano, op. cit., hlm. 281. 
sengketa tersebut ("the tribunal shall apply the law or rules of law that it determines to be appropriate"). Panel arbitrase akan memberikan putusan dengan memperhatikan istilah-istilah yang dipergunakan dalam kontrak yang relevan dan memperhatikan kebiasaan-kebiasaan perdagangan yang berlaku (applicable trade usages) ${ }^{9}$

Mauro Rubino Sammartano di pihak lain juga mengemukakan tentang arti pentingnya masalah pilihan hukum oleh, dan bagi para pihak dalam kaitannya dengan arbitrase internasional yaitu:

"the choice of the applicable substantive
law in international arbitration, if not made
by the parties, is one of the most difficult
issues the arbitrators have to decide". "The
alternative to the application by the arbitrator
of a national law (part from the infrequent
choice of the principles of international law
and of the general principles of the law) is
generally lex mercatoria. However, although
this solution is attractive, is has not been
universally accepted: several judgement and
some authors have rejected it". ${ }^{10}$

Pilihan hukum pada dasarnya hanya dapat dilakukan dalam bidang hukum perjanjian yang memiliki sifat sebagai hukum yang mengatur (regelend recht) dan tidak terhadap hukum yang bersifat memaksa (dwingend recht). Pilihan hukum juga dibatasi pada sistem hukum tertentu saja, yakni yang memiliki hubungan riil dengan dengan substansi perjanjian (the most characteristic connection). Dengan perkataan lain, pilihan hukum tidak dapat diarahkan pada hukum yang tidak ada kaitannya sama sekali dengan substansi perjanjian. Pilihan hukum juga tidak dapat dilakukan dengan maksud sebagai tindakan penyelundupan hukum. Pilihan hukum harus dilakukan dengan maksud-maksud yang baik (made with a bonafide intention) dari pihak-pihak yang terlibat di dalam perjanjian yang bersangkutan.

Kontrak perdagangan internasional merupakan kontrak yang bersifat "cross border" karena melibatkan beberapa sistem hukum (perdata) nasional yang berlainan. Terdapat kecenderungan terjadinya tarik menarik diantara para pihak ketika melakukan negosiasi substansi kontrak yang menyangkut pilihan hukum. Masing-masing pihak cenderung berusaha keras untuk memilih hukum nasionalnya sendiri. Dengan alasan selain substansinya lebih mudah dipahami dibandingkan hukum negara mitra bisnisnya, juga dimaksudkan untuk lebih melindungi kepentingannya sendiri. ${ }^{11}$ Negosiasi kontrak perdagangan, termasuk dalam memilih hukum, akan berlangsung secara dinamis. Pihak yang memiliki posisi tawar lebih kuat memiliki peluang lebih besar untuk mendiktekan kepada pihak yang posisi tawarnya lemah terkait dengan pilihan hukum yang dikehendakinya. Keseimbangan maupun ketimpangan posisi tawar para pihak dalam proses negosiasi akan menentukan kecepatan dan sebaliknya, kelambanan, dalam menghasilkan kesepakatan para pihak. Pihak yang lemah berada dalam situasi dilematis menghadapi pihak yang posisi tawarnya lebih kuat. Dalam situasi demikian berlaku adagium take it or leave it. Oleh karena apabila para pihak saling bersikeras tanpa kompromidantetapmenyatakanmemilih hukum nasionalnya sendiri dan mengabaikan pilihan hukum yang diinginkan oleh mitra bisnisnya,

\footnotetext{
9 Sudargo Gautama, Aneka Hukum Arbitrase (Ke Arah Hukum Arbitrase Indonesia Yang Baru). (Bandung: Citra Aditya, 1996), hlm. 110.

10 Mauro Rubino Sammartano, op. cit., hlm. 251-260.

11 Setiawan, Kontrak Bisnis Internasional: Choice of Law \& Choice of Jurisdiction, Varia Peradilan, No. 107 (1994).
} 
maka proses pembuatan kontrak bisnis akan mengalami kegagalan. ${ }^{12}$ Terbukti bahwa pilihan hukum akan merupakan persoalan yang cukup serius yang perlu diperhatikan bertalian dengan menentukan hukum yang berlaku. ${ }^{13}$

Pada umumnya, dewasa ini para pihak dalam mengadakan kontrak telah melakukan pilihan hukum tertentu agar nantinya tidak menimbulkan kesulitan apabila diantara mereka terjadi sengketa. Kontrak perdagangan internasional yang tidak memuat pilihan hukum akan menimbulkan kesulitan, khususnya tatkala hendak menentukan hukum mana yang berlaku terhadap kontrak maupun akibat hukumnya. Para pihak akan disibukkan untuk berdebat mencari pemecahan terhadap persoalan tersebut, dengan argumentasi teoritisnya masing masing, sementara penyelesaian terhadap substansi sengketa itu sendiri menjadi agak terabaikan. Menurut M. Sumampouw, adanya pilihan hukum oleh para pihak akan menjamin kepastian hukum dan keadilan. Kepastian hukum yang menyangkut tentang penggunaan aturan hukum yang dipilih oleh para pihak terhadap persoalan yang timbul di antara para pihak. Di pihak lain, rasa keadilan akan terpenuhi sejauh mungkin, karena pada akhirnya kepentingan yang bersangkutan dalam perjanjian adalah kepentingan para pihak yang bersangkutan. Dengan demikian tepat apabila kepada para pihaklah pertama-tama diserahkan untuk menentukan hukum mana yang menguasai hubungan mereka. ${ }^{14}$ Meskipun dalam kenyataan yang sesungguhnya sengketa dagang tersebut belum tentu benar-benar terjadi. Bahkan sedapat mungkin dihindarkan agar jangan hal tersebut sampai terjadi.

Suatu pilihan hukum dapat dikatakan sebagai pilihan hukum secara tegas apabila hal tersebut telah dirumuskan dengan katakata atau kalimat tegas (expressis verbis) bahwa para pihak memilih hukum tertentu sebagaimana dituangkan dalam kontrak. Adanya pilihan hukum secara tegas telah dirumuskan secara pasti sekaligus dimaksudkan agar tidak dilakukan interpretasi lain dengan cara sedemikian rupa sehingga menyimpang dari maksud sesungguhnya dari para pihak. Ada kalanya para pihak tidak mencantumkan pilihan hukum secara tegas dalam perjanjiannya. Dalam situasi demikian, terdapat beberapa alternative untuk menentukan hukum yang berlaku. Yansen Dermanto Latip menyebutkan ada 4 alternatif kemungkinan yang dapat dilakukan, yaitu dengan cara: (a). menerapkan hukum dimana kontrak dibuat (lex loci contractus), meskipun hal tersebut masih cukup banyak mengundang kontroversi; (b). menerapkan hukum nasional dari hakim (lex fori) yang akan lebih mudah dan efisien; (c). hukum dari pihak yang paling signifikan terhadap kontrak (the most significant contract relationship) yang mungkin dirasa paling tepat; (d). dugaan hukum yang sepatutnya (putative proper law), hal ini dinilai dapat membingungkan ${ }^{15}$.

Masing masing kemungkinan tersebut dalam penerapannya harus disertai dengan alasan alasan hukum yang logis dan dapat diterima.

12 Sudargo Gautama, Kesulitan Dalam Menyusun Perjanjian Arbitrase Dagang Internasional, Varia Peradilan, No. 25 (1987) hlm. 156.

13 Sudargo Gautama, Hukum Manakah Yang Dipakai Untuk Arbitrase Dagang Internasional, Hukum dan Pembangunan, (Jakarta: Fakultas Hukum Universitas Indonesia, 1989), hlm. 156.

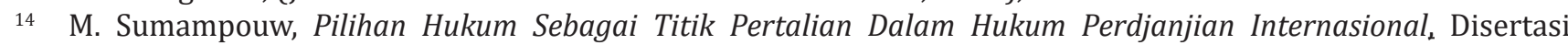
Fakultas Hukum, (Jakarta: Universitas Indonesia, 1968), tidak diterbitkan, hlm. 40 s.d. 43.

15 Yansen Dermanto Latip, op. cit., hlm. 99 sd 160. 
Terdapat kemungkinan bahwa para pihak tidak memandang arti pentingnya mencantumkan pilihan hukum dalam perjanjian. Masalah pilihan hukum baru dirasakan arti pentingnya, manakala diantara para pihak di kemudian hari terjadi sengketa. Bilamana tidak terdapat pilihan hukum secara tegas, maka perlu dilakukan penyelidikan tentang kemungkinan para pihak telah mengadakan pilihan hukum secara diamdiam (implied, tacitly). Untuk menyelidiki adanya pilihan hukum secara diam-diam, maka dapat dilakukan dengan cara menarik kesimpulan berdasarkan maksud, fakta, maupun ketentuanketentuan yang terdapat dalam perjanjian. ${ }^{16}$

Sudargo Gautama, dengan mengutip pendapat Rabel, merumuskan pengertian dari "implied agreement" sebagai berikut: "parties agree tacitly to the application of a particular law when their behavior shows their obligation to be intentionally connected with the orivate law of a certain country". ${ }^{17}$ Adanya pilihan hukum secara diam-diam juga dapat disimpulkan berdasarkan penggunaan bahasa atau mata uang dalam perjanjian, sehingga secara implisit dapat menimbulkan pengertian bahwa para pihak memang telah memilih hukum tertentu terhadap perjanjian maupun akibat yang ditimbulkannya.

Kadang kala dalam perjanjian dagang internasional para pihak saling setuju untuk menyelesaikan sengketanya dengan tidak memilih atau menggunakan hukum nasional dari salah satu pihak. Hal tersebut untuk menghindarkan diri dari kemacetan proses negosiasi pembuatan perjanjian, terutama apabila masing-masing pihak cenderung untuk berusaha memaksakan berlakunya hukum nasional masing-masing terhadap perjanjian maupun penyelesaian sengketa yang mungkin terjadi. Namun demikian tidak adanya pilihan hukum oleh para pihak dalam kontrak akan menimbulkan kesulitan untuk memastikan hukum yang tepat diberlakukan terhadap kontrak. Apabila terjadi sengketa para pihak, maka hakim atau arbiter akan memutus sengketa berdasarkan prinsip prinsip dalam hukum perdata internasional yang berlaku. Hakim atau arbiter harus berusaha menemukan dan menciptakan hukum dengan menggunakan sebagai pisau analisis, berbagai pilihan teori dalam hukum perdata internasional, antara lain: (a). the proper law theory, yang menyangkut hukum yang sebenarnya dipikirkan dan diniatkan oleh para pihak; (b). lex loci contractus, menurut teori ini, hukum yang berlaku terhadap kontrak adalah hukum dimana kontrak itu dibuat; (c). lex loci solutionis, menurut teori ini hukum yang berlaku adalah hukum di tempat dimana perjanjian dilaksanakan; (d). lex fori, menurut teori ini hukum yang berlaku terhadap kontrak adalah hukum dari hakim yang menyelesaikan sengketa; (e). the mostcharacteristic connection, menurut teori ini hukum yang berlaku terhadap kontrak adalah hukum yang didasarkan pada hukum salah satu pihak yang melakukan prestasi paling karakteristik dalam suatu transaksi. ${ }^{18}$

Dengan adanya kesepakatan untuk tidak memilih dan menggunakan berlakunya hukum nasional masing-masing pihak, melainkan menggunakan ketentuan hukum kebiasaan

16 Purnadi Purbacaraka dan Agus Brotosusilo, Sendi-Sendi Hukum Perdata Internasional: Suatu Orientasi, (Jakarta: Rajawali, 1989), hlm. 177.

17 Sudargo Gautama, op. cit, hlm. 40-41.

18 Sudargo Gautama, Hukum Perdata Internasional Indonesia, Jilid III, Bagian 2, Buku ke-8, (Bandung: Alumni, 2002), hlm. 8-47. 
atau berdasarkan pada praktek perdagangan internasional yang sudah umum dipakai, yang dikenal sebagai "lex mercatoria".

Lex Mercatoria disebut juga sebagai "the Mercantile Law" atau "the Law of Merchant". Black's Law Dictionary merumuskannya sebagai berikut:

".....a system of customary law that developed in Europe during the Middle Ages and regulated the dealings of mariners and merchants in all commercial countries of the world until the $17^{\text {th }}$ century. Many of the Law Merchants principle's came to be incorporated into the common law, which in turn formed the basis of the Uniform Commercial Code". ${ }^{19}$

Dengan menggunakan "lex mercatoria" maka para pihak akan berhadapan dalam derajat yang sama. Tidak ada pihak yang merasa dirugikan karena harus diberlakukan terhadap ketentuan hukum asing atau hukum Negara pihak lawannya. Selanjutnya Mauro Rubino Sammartano mengemukan bahwa: "lex mercatoria must consequently be applied when the parties have excluded any national law and have asked the arbitrators to apply only the general principles and usages of international trade". ${ }^{20}$

Persoalan akan timbul apabila ternyata para pihak tidak mengadakan pilihan hukum, baik yang dilakukan secara tegas maupun yang dilakukan secara diam-diam, sehingga tidak diketahui secara pasti hukum apa yang sebenarnya dikehendaki oleh para pihak agar diterapkan terhadap penyelesaian sengketa tersebut. Dalam hal terjadi demikian, maka yang melakukan pilihan hukum adalah arbitrator atau para arbitrator. Hal tersebut sebagaimana dikemukan oleh Mauro Rubino Sammartano bahwa:

"in the absence of a choice by the parties, the arbitrators choose the applicable law. This means there are has not even been a tacit choice by the parties. In fact, when the arbitrators establish that there has been a tacit choice by the parties, they confine themselves to stating a choice which has already been made by the latter". The choice by arbitrator of the applicable law, based on the place of arbitration, meets the same obstacles which, it is suggested, do not allow a tacit choice by the parties to inferred from it. ${ }^{21}$

\section{b. Pilihan Forum Penyelesaian Sengketa}

Penyelesaian sengketa kontrak perdagangan pada dasarnya dapat dilakukan di muka pengadilan (in/by court dispute resolution) maupun dilakukan di luar pengadilan (out of court dispute resolution). Penyelesaian sengketa di muka pengadilan akan dilakukan oleh badan peradilan negara (state court) dari satu pihak dalam kontrak. Adapun penyelesaian sengketa perdagangan juga dapat dilakukan melalui mekanisme yang bersifat out of court meliputi pilihan melalui negosiasi, mediasi, konsiliasi, med-arb (hybrid), arbitrase atau cara yang lain yang disepakati. Pemilihan forum penyelesaian sengketa kontrak perdagangan harus disesuaikan dengan karakteristik sengketa perdagangan itu sendiri, berdasarkan prinsip efisiensi, efektifitas, profesionalitas, serta kalkulasi peluang (chance) untuk memenangkan perkara, serta kemudahan prosedur dan proses pelaksanaan putusannnya.

\footnotetext{
9 Bryan A Garner (ed), op. cit., hlm. 893 dan 923.

20 Mauro Rubino Sammartano, loc. cit.

21 Mauro Rubino Sammartano, Op. Cit., HIm. 257.
} 


\section{RECHTSVINDING}

Media Pembinaan Hukum Nasional

Para pihak dalam kontrak perdagangan internasional, pada umumnya cenderung memilih forum penyelesaian sengketa melalui arbitrase. Sangat jarang ditemukan memilih penyelesaian sengketa kontrak perdagangan internasional melalui forum pengadilan nasional dari salah satu pihak dalam kontrak. Selain alasan ketidakpahaman terhadap sistem dan proses peradilan negara setempat berikut dengan segala kerumitan dan kelambanan prosesnya, juga disebabkan adanya kekuatiran yang menyangkut potensi ancaman terhadap independensi dan imparsialitas hakim.

Arbitrase yang dipilih, dapat berupa arbitrase institusional atau arbitrase ad hoc, arbitrase nasional atau arbitrase internasional. Pencantuman klausula penyelesaian sengketa (dispute settlement clause) acapkali ditemukan dalam kontrak dagang internasional. Dengan menunjuk lembaga arbitrase tertentu, misalnya International Chamber of Commerce (ICC) Court of Arbitration, Singapore International Arbitration Center (SIAC), London Court of Internationl Arbitration (LCIA), Badan Arbitrase Nasional Indonesia (BANI) atau lembaga arbitrase lainnya sebagainya. Kesepakatan para pihak dalam memilih forum arbitrase dituangkan dalam klausula arbitrase (arbitration clause atau pactum de compromitendo) yang menyatu dalam kontrak induk yang dibuat sebelum terjadi sengketa, atau dalam bentuk perjanjian arbitrase (arbitration agreement atau acta van compromise) dalam bentuk tersendiri dan terpisah dari kontrak induknya dan dibuat setelah sengketa terjadi. Esensi dan akibat hukum keduanya pada dasarnya adalah sama, bahwa para pihak telah bersepakat untuk memilih arbitrase sebagai forum penyelesaian sengketa, sekaligus secara melepaskan haknya
Volume 7, Nomor 2, Agustus 2018

untuk mengajukan sengketa kontrak ke muka pengadilan.

Secara teoritis, penyelesaian sengketa bisnis melalui arbitrase terasa lebih efektif dan efisien dibandingkan melalui lembaga peradilan. Proses arbitrase terikat dengan durasi waktu tertentu (time limitation) yang ditentukan berdasarkan undang undang, aturan prosedur badan arbitrase maupun kesepakatan para pihak. Adapun proses pada peradilan, waktu penyelesaian sengketa cukup sukar untuk dipastikan kapan endingnya. Disebabkan karena struktur pengadilan bertingkat tingkat, membuka berbagai penggunaan berbagai upaya hukum yang berdampak pada ekstensi waktu dan biaya. Pemeriksaan arbitrase dilakukan oleh arbitrator yang memiliki spesifikasi keahlian sesuai dengan karakteristik sengketa (expert in the subject matter of disputes) sedangkan hakim dalam proses peradilan memiliki keahlian yang sangat umum. Proses arbitrase berlangsung secara tertutup (private and confidential) sehingga terhindar dari publikasi subyek dan obyek sengketa yang justru dapat merugikan para pihak. Sedangkan proses litigasi di muka pengadilan bersifat terbuka untuk untuk umum.

Putusan arbitrase bersifat final and binding sedangkan putusan pengadilan terbuka untuk dimintakan berbagai upaya hukum sampai dengan ada putusan yang berkekuatan tetap. Putusanarbitrase memilikikekuatan eksekutorial apabila tidak dipenuhi secara suka rela oleh pihak yang dihukum atau dikalahkan. Putusan arbitrase internasional dapat dimohonkan pengakuan dan pelaksanaan dinegara lain yang berbeda dengan negara di tempat putusan arbitrase dijatuhkan. Sepanjang negara negara tersebut merupakan peserta dan meratifikasi New York Convention 1958, Convention on the Recognition and Enforcement of Foreign Arbitral 
Award. Indonesia merupakan salah satu negara peserta yang telah meratifikasi Konvensi New York berdasarkan Keppres No.34 Tahun 1981.

Di Indonesia, arbitrase diatur dalam UUAAPS. ${ }^{22}$ Berdasarkan Pasal 34 (1) UUAAPS para pihak dapat memilih penyelesaian sengketa melalui lembaga arbitrase nasional maupun arbitrase internasional. Pilihan tersebut didasarkan kesepakatan tertulis yang ditandatangani oleh para pihak. Pasal 1 ayat (9) UUAAPS mengatur pengertian "Putusan Arbitrase Internasional" adalah putusan yang dijatuhkan oleh suatu lembaga atau arbiter perorangan di luar wilayah hukum Republik Indonesia, atau putusan suatu lembaga arbitrase atau arbiter perorangan yang menurut ketentuan hukum Republik Indonesia dianggap sebagai suatu putusan arbitrase internasional".

Mauro Rubino Sammartano memberikan ilustrasi disertai dengan contoh perbedaan kategori antara arbitrase nasional dengan arbitrase internasional (the categories of national and foreign arbitration) sebagai berikut:

".......for example, Swedish law (Foreign Arbitration Agreements and Awards Act No.147/1929) defines as "foreign" that arbitration which takes place in a foreign country, or in Sweden, but in which one of the parties is not Swedish..........". "......in English Law (Arbitration Act 1979) defines as domestic arbitrations which take place in the United Kingdom, if the parties to them are UK citizens at the time they enter into submission agreement...". "...However, arbitration which takes place in a given state, but contains elements external to that legal system, is generally treated as international arbitration...". "......As we have seen, the recurring definition of international arbitration is based on the different nationality, or domicilie, of the parties to the proceeding $s^{23}$

Forum arbitrase mana yang akan dipilih, sepenuhnya bergantung pada kesepakatan para pihak. Dengan adanya kesepakatan yang dibuat para pihak menyangkut pilihan forum mengikat para pihak, oleh karenanya berlaku prinsip "pacta sunt servanda" dimana pihakpihak berkewajiban untuk mematuhi dan melaksanakan kesepakatan dengan itikad baik. ${ }^{24}$ Dengan adanya klausula arbitrase (arbitration clause) maupun perjanjian arbitrase (arbitration agreement) maka hal itu berarti para pihak telah melepaskan haknya untuk mengajukan sengketa melalui lembaga peradilan. Hal ini telah diakomodasi dalam Pasal 3 UUAAPS. Apabila terdapat pihak yang sejak awal sudah mengadakan perjanjian arbitrase namun tetap saja memaksakan diri mengajukan sengketa ke pengadilan, maka patut dipertanyakan latar belakang motif dan itikad baiknya untuk menghargai kesepakatan yang telah dibuatnya sendiri.

Pasal 37 (1) UUAAPS mengatur tentang pemilihan tempat arbitrase oleh arbitrator

22 Mencabut ketentuan arbitrase yang diatur dalam Pasal 615 sd 651 Reglement op de Rechtsvoerdering Staatblaad 1847: 52 dan Pasal 377 Het Herziene Indonenische Reglement Staatblaad 1941: 44 dan Pasal 705 Rechtsreglement Buitengewesten, Staatblaad 1927: 227.

23 Ibid., hlm. 15-17

24 Menurut Bertold Goldman, sebagaimana dikutip oleh Huala Adolf, bahwa prinsip "Pacta Sunt Servanda" mengandung beberapa pengertian sebagai berikut: (1). The obligation of each party to a contract to fulfill its promises (kewajiban setiap pihak untuk memenuhi janjinya); (2). The obligation to perform them in good faith (kewajiban untuk melaksanakan janjinya dengan itikad baik); (3). To compensate for the damage caused to the other party by their non fulfillment (kewajiban mengganti kerugian terhadap pihak lain akibat perbuatannya. Huala Adolf, Arbitrase Komersial Internasional, (Jakarta: Rajawali, 1993) Hlm. 53. 
atau majelis arbitrase, kecuali ditentukan sendiri oleh para pihak. Terkandung makna bahwa para pihak memiliki otonomi untuk memilih dan menentukan tempat arbitrase. Kecuali apabila para pihak tidak memilih dan menentukan tempat arbitrase maka tempat arbitrase ditentukan oleh arbitrator atau majelis arbitrase. Masalah tempat arbitrase sangat penting berkenaan dengan adanya unsur hukum asing. Lagi pula substansi kontrak maupun sengketa masuk ke dalam ranah hukum perdata internasional. Berkaitan dengan persoalan tersebut, Gary B. Born mengemukan tentang arti pentingnya menentukan tempat arbitrase sebagai berikut:

\begin{abstract}
"The geographic location of arbitral proceedings is of great importance in any arbitration. The arbitral situs ussualy determines the national law pelaksanaan putusan arbitrase internasional yang bersangkutan di kemudian hari. Menurut Konvensi New York 1958 (Convention on the Recognition and Enforcement of Foreign Arbitral Award), bahwa suatu putusan arbitrase internasional dapat dilaksanakan di wilayah suatu negara, apabila terlebih dahulu mendapatkan pengakuan (recognition) dari negara bersangkutan, selanjutnya putusan dapat dijalankan (enforcement). Ketentuan tersebut hanya berlaku bagi negara-negara peserta atau negara negara yang telah meratifikasi Konvensi New York 1958 ke dalam sistem hukum nasionalnya masing-masing. Indonesia telah meratifikasi Konvensi New York 1958 berdasarkan Keppres No.34/1981.
\end{abstract}

Menurut Martin Hunter, alasan para pihak mengadakan pilihan tempat penyelenggaraan arbitrase menyangkut dua hal yakni: (1) the enforceability of the award, and (2) a favourable legal environment. ${ }^{25}$ Pilihan tempat kedudukan lembaga arbitrase memiliki arti dan konsekuensi yang sangat penting. Berkaitan dengan arbitrase internasional, maka negara di tempat proses dan putusan arbitrase dijatuhkan akan menentukan apakah putusan tersebut dapat dimintakan pengakuan (recognition) serta dapat dilaksanakan (enforceable) di wilayah negara yang lain ataukah tidak. Apakah masing masing negara tersebut peserta Konvensi New York 1958 ataukah tidak. Berlaku konsekuensi yuridis, apabila ternyata negara di tempat putusan arbitrase dijatuhkan dengan negara di tempat negara negara tersebut bukan termasuk negara-negara yang meratifikasi Konvensi New York 1958, maka putusan arbitrase tersebut tidak dapat dimintakan pengakuan maupun pelaksanaannya. Selain meratifikasi Konvensi, disyaratkan pula adanya hubungan diplomatik dan perjanjian bilateral dan resiprokal mengenai hal tersebut diantara negara negara yang bersangkutan. Tindakan ratifikasi terhadap Konvensi New York 1958 masih harus ditindaklnjuti dengan mengatur secara lebih teknis ke dalam hukum nasionalnya masingmasing.

Alasan kedua dalam memilih tempat arbitrase internasional menurut Martin Hunter, menyangkut favourable legal environment. Lingkungan hukum yang favourable, mengandung makna bahwa negara di tempat penyelenggaraan maupun putusan arbitrase, haruslah negara yang memiliki sistem hukum yang mantap serta dalam situasi dan kondisi sosial politik yang stabil. Hal-hal tersebut dapat menjadi bahan pertimbangan. Para pihak harus memiliki keyakinan adanya jaminan rasa aman bahwa proses arbitrase akan berlangsung dengan baik, lancar, obyektif, independen, serta

\footnotetext{
Martin Hunter et.al., The Freshfields Guide to Arbitration and ADR: Clauses in International Contracts, (Deventer:
} Kluwer, 1993), hlm. 19-24. 
putusannya dapat dilaksanakan di kemudian hari.

Martin Hunter, menyebutkan terdapat beberapa negara yang dinilai memiliki " $a$ favourable legal environment" yakni:

France, Switzerland, Belgium United Kingdom, Germany, Netherlands (Western Europe), Austria (Eastern Europe), Tunisia (North Africa), Cote d'lvore (Sub Sahara Africa), India, Pakistan (Asia), Columbia, Mexico (Latin America), United States (North America), Greece, Cyprus, Jordan (Eastern Mediterranean). ${ }^{26}$

Pertanyaannya, mengapa Indonesia tidak dimasukan dalam kategori negara yang dinilai memiliki "a favourable legal environment", perihal tersebut dapat kita analisis sendiri apa yang menjadi penyebabnya.

Persoalan akan timbul apabila para pihak tidak sejak awal menetapkan pilihan tempat arbitrase dan ketika terjadi sengketa, atau mereka tidak mencapai kesepakatan dalam menentukan tempat arbitrase. Terhadap persoalan tersebut, Mauro Rubino Sammartano menyatakan bahwa:

In institutional arbitrations, the choice of the place of arbitration, failing agreement between the parties, is generally made by the arbitral institution before it appoints the arbitrators or the chairman of the arbitral tribunal. In ad hoc arbitration, in the case of silence by the parties, the choice is generally made by arbitrators.

In both cases this frequently takes place without consulting the parties, as if, because they had not reached agreement earlier, a discussion with them could not be useful for making a choice. A place which is very convenient for one party and inconvenient for the other may the create financial difficulties and also limit the possibility of presenting one's case $^{27}$

Menurut pendapat saya, kesulitan tersebut seharusnya tidak perlu terjadi apabila sejak awal dalam pembuatan kontrak, para pihak telah mencantumkan ke dalam klausula arbitrase secara tegas dengan menunjuk suatu lembaga arbitrase internasional tertentu yang berada di negara tertentu, yang akan menyelenggarakan proses dan putusan arbitrase.

\section{Pembaruan Hukum Perdata Internasional}

Bahan Pembinaan Hukum Nasional (BPHN) Kementerian Hukum dan HAM, pada tahun 2014, telah menghasilkan sebuah Naskah Akademik dan Rancangan Undang Undang (RUU) tentang Hukum Perdata Internasional. Tim penyusun berasal dari kalangan kampus yang memiliki pengalaman dan keahlian di bidangnya. RUU tersebut dimaksudkan untuk menggantikan ketentuan hukum perdata internasional peninggalan colonial, yaitu ketentuan Pasal 16, 17 , dan 18 Algemene Bepalingen van Wetgeving voor Nederlands Indie (AB) Staatblaad 1847 No. 23 yang dinilai sudah tidak sesuai lagi dengan dinamika kebutuhan saat ini terkait dengan dinamika globalisasi perdagangan.

Naskah Akademik sebagai hasil suatu riset dan kajian ilmiah yang dilakukan secara mendalam untuk memberikan alasan alasan ilmiah mengenai latar belakang mengapa perlu segera dilakukan pembaruan hukum terhadap ketentuan dasar yang mengatur tentang hukum perdata internasional di Indonesia yang berlaku selama ini. Pembuatan Naskah Akademik tersebut disyaratkan dalam UU No.12

\footnotetext{
26 Ibid.

27 Mauro Rubino Sammaratano, loc. cit.
} 
tahun 2011 tentang Pembentukan Peraturan Perundang-undangan terkait dengan penyiapan dan penyusunan sebuah RUU. Berdasarkan Naskah Akademik tersebut selanjutnya telah dirumuskan ke dalam sebuah RUU yang diberi judul RUU tentang Hukum Perdata Internasional. RUU Hukum Perdata Internasional sebagai lus Constituendum tersebut nantinya berfungsi sebagai kodifikasi peraturan peraturan menyangkut hukum perdata international yang disesuaikan dengan dinamika perkembangan hukum perdata internasional pada saat sekarang ini. Karena Indonesia dalam beberapa dekade belakangan ini telah terlibat secara aktif dalam berbagai aktifitas perdagangan internasional dengan negara lain sehingga memerlukan kaidah hukum nasional, dalam bentuk undang undang, yang mengatur masalah hukum perdata internasional.

Upaya pembaruan hukum tersebut patut disambut dengan gembira, mengingat telah sekian lama belum dilakukan pembaruan hukum terhadap berbagai peraturan perundang undangan kolonial yang berdasarkan Pasal II Aturan Peralihan Undang Undang Dasar 1945 "terpaksa" diberlakukan kembali untuk mengisi kekosongan hukum dan selama belum diadakan yang baru sebagai penggantinya. Di antara berbagai peraturan perundang undangan kolonial tersebut satu diantaranya adalah pasal 16, 17 dan $18 A B$ yang selama ini menjadi landasan hukum terkait dengan hukum perdata internasional.

Padahal semangat yang terkandung dalam Pasal II Aturan Peralihan tersebut sangat jelas, bahwa diberlakukannya kembali berbagai peraturan perundang undangan yang sudah ada sebelum kemerdekaan Indonesia adalah bersifat sementara, yaitu selama belum diadakan yang baru menurut Undang Undang
Dasar 1945. Sifat kesementaraan tersebut tidak boleh dibiarkan terus berlarut larut, terlena sehingga tanpa disadari waktu terus bergerak, yang hingga saat ini sudah memasuki 73 tahun Indonesia merdeka. Padahal seharusnya ketentuan ketentuan colonial yang berlaku, termasuk Pasal 16, 17 dan 18 AB tersebut, harus segera digantikan dengan peraturan perundang undangan baru yang dibuat oleh Pemerintah Indonesia yang disesuaikan dengan kebutuhan aktual dan mendesak pada saat ini. Politik hukum nasional yang terkait dengan pembaruan hukum perdata internasional merupakan upaya sistematis untuk merumuskan arah dan tujuan yang jelas dan pasti sesuai dengan amanat Undang Undang Dasar 1945. RUU Hukum Perdata Internasional pada bagian menimbang menyebutkan bahwa:

a. Bahwa untuk mewujudkan tujuan pembentukan Pemerintahan Negara Indonesia yang melindungi segenap bangsa Indonesia dan seluruh tumpah darah Indonesia serta memajukan kesejahteraan umum, dan mencerdaskan kehidupan bangsa, diperlukan ada jaminan kepastian hukum bagi masyarakat untuk melakukan aktivitasnya dalam rangka globalisasi di berbagai bidang;

b. Bahwa dengan perkembangan globalisasi yang semakin pesat di bidang ekonomi, sosial, budaya, ilmu pengetahuan dan teknoogi pada dewasa ini, telah memberikan warna dalam perkembangan hukum sehingga perlu adanya kodifikasi hukum sebagai perangkat aturan aturan hukum yang tersusun secara sistematis dan dapat memberikan petunjuk ke arah penyelesaian secara adil bagi persoalan persoalan hukum yang mengandung unsur asing; 
c. Bahwa Pasal 16,17 dan 18 AB yang selama ini digunakan dalam permasalahan hukum perdata internasional sudah tidak sesuai lagi dengan perkembangan kebutuhan masyarakat, sehingga perlu dibentuk suatu undang undang untuk menjamin kepastian hukum masyarakat.

Konsiderans huruf $\mathrm{a}, \mathrm{b}$ dan $\mathrm{c}$ tersebut telah memberikan penegasan tentang alasan mengapa UU Hukum Perdata Internasional perlu dibuat. Terkandung suatu penegasan bahwa diperlukan adanya jaminan kepastian hukum sekaligus sebagai petunjuk penyelesaian persoalan hukum yang di dalamnya mengandung unsur asing dalam kegiatan perekonomian global. Keikutsertaan dalam aktifitas perekomian global dilakukan sedemikian rupa namun tetap dalam rangka melindungi hak dan kepentingan warga negara dan negara Indonesia dalam hal terjadi persoalan hukum.

Bagaimanapun juga tujuan negara yang telah ditetapkan dalam Pembukaan Undang Undang Dasar 1945, yang diantaranya memuat frasa yang berbunyi: ........melindungi segenap tumpah darah Indonesia serta memajukan kesejahteraan umum tetap menjadi landasan utama dalam melakukan pembaruan hukum tersebut. Satu dan lain hal, ketentuan hukum perdata internasional yang berlaku selama ini, pasal 16, 17 dan 18 AB dibuat oleh Pemerintah Kolonial, sehingga karenanya memuat alasan filsofis serta suasana kebatinan Pemerintah Kolonial yang sudah tidak sesuai lagi dengan Indonesia yang telah 73 tahun merdeka dalam konteks globalisasi pada saat ini. Dalam beberapa dekade ini, Indonesia telah melakukan berbagai pembaruan hukum secara sektoral yang memiliki keterkaitan dengan masalah hukum perdata internasional. Indonesia juga telah meratifikasi berbagai Konvensi Internasional yang di dalamnya mengatur tentang masalah masalah yang terkait dengan hukum perdata internasional. Indonesia juga telah menandatangani berbagai kesepakatan dalam perjanjian internasional dengan negara negara yang lain yang terkait dengan ekonomi perdagangan.

Dapat dikatakan bahwa dalam era globalisasi ekonomi perdagangan saat ini batas batas negara menjadi borderless sehingga terjadi pertukaran arus barang dan jasa antara Indonesia dengan negara yang lain berjalan demikian pesat. Kegiatan ekspor dan impor antara Indonesia dengan negara mitranya menjadikan kegiatan ekonomi perdagangan berlangsung demikian pesat. Kesemua aktifitas tersebut sudah barang tentu memiliki implikasi hukum, khususnya hukum perdata internasional, karena menyangkut hubungan hukum antara Indonesia, baik negara, korporasi maupun subjek hukum perorangan dengan mitra dagangnya di negara lain, baik negara, korporasi serta subyek hukum perorangan. Hubungan hukum di bidang ekonomi perdagangan tersebut dituangkan ke dalam kontrak dagang internasional, karena mengandung adanya unsur hukum asing, yaitu hukum dari mitra dagangnya yang berasal dari negara lain. Pengaturan dalam RUU Hukum Perdata Internasional menjadi sangat penting untuk segera diundangkan, dalam rangka memberikan kepastian hukum bagi para pihak yang mengadakan hubungan kontrak dagang internasional maupun bagi hakim dalam terjadi sengketa di antara para pihak.

\section{Penutup}

Dalam negosiasi perumusan setiap kontrak dagang internasional diperlukan kehati-hatian dan kecermatan dari para pihak terhadap 
segala rumusan klausula dan substansi yang akan dimuat di dalamnya. Merupakan hal yang sangat penting untuk diperhatikan oleh para pihak yakni klausula yang menyangkut tentang pilihan hukum yang berlaku terhadap kontrak serta pilihan forum untuk menyelesaikan sengketa yang mungkin timbul terkait dengan pelaksanaan kontrak. Ketepatan melakukan pilihan hukum akan menentukan keabsahan kontrak, penerapan hukum yang berlaku terhadap kontrak.

Ketepatan melakukan pilihan forum dan mekanisme yang tepat untuk menyelesaikan kemungkinan terjadinya sengketa kontrak di kemudian hari. Penyelesaian sengketa kontrak dagang internasional lebih tepat apabila dilakukan melalui forum arbitrase internasional yang disepakati, dimana arbitrase internasional tersebut dinilai memiliki reputasi tinggi serta putusannya dapat dimintakan pengakuan dan pelaksanaan di negara negara dari pihak yang menandatangani kontrak dagang internasional tesebut.

Negara negara yang telah meratifikasi New York Convention 1958, yaitu Konvensi tentang Pengakuan dan Pelaksanaan Putusan Arbtrase Asing/Internasional, serta memiliki hubungan bilateral dengan pihak Indonesia.

Substansi ketentuan Pasal 16, 17 dan 18 AB yang dibuat oleh Pemerintah Kolonial sudah ketinggalan jaman, sudah tidak sesuai dengan kebutuhan Indonesia pada saat ini serta tidak sesuai lagi dengan dinamika perdagangan internasional, sehingga perlu segera dicabut dan diganti dengan hukum perdata internasional yang dibuat oleh Pemerintah Indonesia. Politik hukum yang menyangkut pembaruan hukum dengan memberlakukan UU tentang Hukum Perdata Internasional merupakan kebutuhan mendesak dalam rangka Indonesia meningkatkan perekonomian Indonesia terkait dengan globalisasi perdagangan. Badan Pembinaan Hukum Nasional (BPHN) perlu segera menyempurnakan RUU Hukum Perdata Internasional yang sudah ada dengan meminta masukan (lagi) dari para pemangku kepentingan (stake holder) sebelum mengajukan ke Pemerintah agar diajukan sebagai RUU inisiatif Pemerintah dan dimasukkan ke dalam Prioritas - Program Legislasi Nasional.

\section{Daftar Pustaka}

\section{Buku}

Adolf, Huala, Arbitrase Komersial Internasional, (Jakarta: 1991).

Adolf, Huala, Dasar Dasar Hukum Kontrak Internasional, (Bandung: Refika Tama, Bandung, 2007).

Adolf, Huala, Instrumen Instrumen Hukum Tentang Kontrak Internasional, (Bandung: Keni Media, 2011).

Born, Gary B., International Commercial Arbitration in the United States, (GA Deventer: Kluwer Law and Taxation Publishers, 1994).

Boyle, Fiona, et.al., A Practical Guide to Lawyering Skills, (London: Cavendish Publising Limited, 2002).

Dzienkowski, John S., Professional Responsibility Standards, Rules and Statutes, (Minn: West Group, 1998).

Freeman, John H., Client Management for Socilicitors, (London: Cavendish Publishing Limited, 1997).

Garner, Bryan A., Blacks Law Dictionary, 8 edition, (St,Pau Minn: West Publsihing Co, 1999).

Gautama, Sudarto, Pengantar Hukum Perdata Internasional, (Bandung: Binacipta, Bandung, 1987).

Gautama, Sudarto, Aneka Hukum Arbitrase (Ke Arah Hukum Arbitrase Indonesia Yang Baru (Bandung: Citra Aditya, 1996).

Gautama, Sudarto, Hukum Perdata Internasional, Buku ke-5, Jilid II, Bagian IV, (Bandung: Alumni, 1992).

Hunter, Martin, et.al., The Freshfields Guide to Arbitration and ADR: Clauses in International Contracts, (Deventer: Kluwer, 1993). 
Kian, Chaterine Tay Swee, Resolving Disputes by Arbitration: What You Need to Know, (Singapore: Ridge Books, Singapore University Press, 1998).

Purbacaraka, Purnadi dan Agus Brotosusilo, SendiSendi Hukum Perdata Internasional: Suatu Orientasi, (Jakarta: Rajawali, 1989).

Rau, Allan Scott, et al., Processes of Dispute Resolution: The Role of Lawyers, third edition, (New York: University Casebooks Series, Foundation Press, 2002).

Sammartano, Mauro Rubino, International Arbitration Law, (GA Deventer: Kluwer Law and Taxation Publishers, 1990)

Stephen Gillers, Regulation of Lawyers: Problems of Law and Ethics, Fifth edition, (New York: Aspen Law \& Bussiness, 1998).

\section{Makalah/Artikel/Prosiding/Hasil Penelitian}

Gautama, Sudargo, "Kesulitan Dalam Menyusun Perjanjian Arbitrase Dagang Internasional", Varia Peradilan, No. 25 (1987).
Latip, Pilihan Hukum dan Piihan Forum Dalam Kontrak Internasional, Disertasi, Universitas Indonesia, Fakultas Hukum, Program Pascasarjana (2002).

Purbacaraka, Purnadi dan Agus Brotosusilo, "Kontrak Bisnis Internasional: Choice of Law \& Choice of Jurisdiction", Varia Peradilan, No. 107 (1994).

Setiawan, "Pengaruh Mandatory Rules Terhadap Kontrak Bisnis Internasional: Catatan Dari Jurisprudensi", Varia Peradilan, No. 98 (1993).

Setiawan, "Hukum Manakah Yang Dipakai Untuk Arbitrase Dagang Internasional, Hukum dan Pembangunan, Fakultas Hukum, Universitas Indonesia (1989).

Sumampouw, M., Pilihan Hukum Sebagai Titik Pertalian Dalam Hukum Perdjanjian Internasional ${ }_{2}$ Disertasi, Fakultas Hukum Universitas lindonesia, 1968, tidak diterbitkan. 
"Halaman ini dikosongkan" 